\title{
The ever-transcending quest in the poetry of Sri Chinmoy: the human quest for God-Realisation; God's quest for manifestation
}

\author{
Mrinali C Clarke
}

Correspondence: mrinalicc@gmail.com Sri Chinmoy Centre, 21 Studley Park Road, Melbourne 3101, Australia

\begin{abstract}
Background: This is a discussion paper that sets out to explore an approach to the writings of the spiritual master Sri Chinmoy, through the motif of the Quest. In particular, it explores his own journey to God-realisation, or Self-realisation, and his teaching of the interdependence of the relationship between aspiring humanity and the ever-transcending nature of the Supreme Being.

Discussion: The Quest is defined in general terms as a journey towards humanity's inner divinity, and corresponds to the three traditional steps of Separation, Trial and Return, which are illustrated throughout the writings, particularly in the poetry. The human soul, separated from the divine Oneness of existence, descends into the physical world to enter God's Cosmic Game of hide and seek. Endless trials and cycles of life eventually awaken man to his higher purpose and fulfillment in seeking union with the Beloved. It is aspiration through the heart that Sri Chinmoy claims will cause the descent of divine Compassion and the bestowing of the Union, and he illustrates this through his own journey to the highest. He portrays the exalted states of blissful absorption in the divine Consciousness, and illustrates that his poetry and writings then become a pathway for all seekers to enter a higher state of consciousness - which he calls the 'manifestation', the divine purpose of God to fulfil himself and humanity at the same time.

Summary: The cross-referencing of Sri Chinmoy's poetry and prose writings both supports and explains many of the mysteries of the ever-transcending Quest of the Supreme for divine manifestation in the sphere of the physical world and offers a bright new path of spirituality which itself transcends boundaries of East and West.
\end{abstract}

Keywords: Poetry; Quest; Spiritual evolution

\section{Background}

\author{
We all know \\ That God is great. \\ We all know \\ That God is good. \\ But do we know \\ That God is our own \\ Highest Self. \\ Sri Chinmoy ${ }^{a}$
}


Sri Chinmoy always called himself 'an Indian village boy'. He was born 27th August, 1931 in the tiny village of Shakpura, Chittagong, East Bengal, the seventh child of Shashi Kumar Ghose (father) and Yogamaya Biswas (mother). His father, unusually for the time of the British Raj, had worked his way up to become Chief Inspector of the Assam-Bengal Railway, and later owned and ran a bank. However, as a somewhat mischievous, restless barefoot child the youngster Chinmoy would, rather than attend school, accompany his father to work, and run off roaming the town, or spend hours observing the foibles of human nature at the court-house. Orphaned at the age of 12, he joined his brothers and sisters at the Sri Aurobindo Ashram as was his mother's wish. It was not prosperous ${ }^{\mathrm{b}}$, but it was a centre of cultural, literary and intellectual life where Chinmoy immediately immersed himself in the practice of meditation, starting at 3 am each day. By the age of 13 he was spending many hours in the state of Samadhi, or trance, recognised as a state of enlightenment. He began expressing these higher experiences in his poetry. Later he would explain:

There are various minor samadhis, and among the minor samadhis, savikalpa samadhi happens to be the highest. Right after savikalpa comes nirvikalpa samadhi, but there is a great yawning gulf between savikalpa and nirvikalpa. In savikalpa samadhi there are thoughts and ideas coming from various angles, but they do not affect you... But when you are a little higher, when you have become one with the soul in nirvikalpa samadhi, there will be no ideas or thoughts at all. There nature's dance stops. There is no nature, only infinite peace and bliss. The Knower and the known have become one. Everything is tranquil. There you enjoy a supremely divine, all-pervading, self-amorous ecstasy... Sahaja samadhi is by far the highest type of samadhi. In this samadhi one is in the highest consciousness, but at the same time he is working in the gross physical world. One maintains the experience of nirvikalpa samadhi while simultaneously entering into earthly activities ${ }^{c}$.

At age 14 Sri Chinmoy had already written 200 poems of his own in Bengali. He rendered Sri Aurobindo's Bengali story, "Kshamar Adarsha", "The Ideal of Forgiveness", into Bengali verse - 200 lines of pure Bengali metre. Teaching himself English, later he would spend much time translating ashram articles from Bengali. In 1957, Chinmoy translated an article from Bengali into English blank verse, written by Nolini Kanta Gupta, the Secretary General of the Ashram, recognised as an intellectual giant. Nolini summoned Chinmoy and immediately appointed him as his personal secretary and translator, explaining that he had never been satisfied with others' translations of his work ${ }^{\mathrm{d}}$. Chinmoy remained at the ashram until 1964, immersed in literary activities and spiritual discipline. He claimed that his early years at the ashram were like revising the book of God-realisation, an experience he had achieved in earlier incarnations.

My Supreme, my Supreme, my Supreme!

Out of Your Infinite Bounty,

Centuries ago You blessed me

With God-realisation

That far transcended

Heaven's Summits . 
Responding to an inner command from his Beloved Supreme, or Inner Pilot as he termed his inner communion, he removed to New York to begin his own mission. The culture shock he would have experienced is illustrated by his amusing story of not knowing what to do with a tea bag and hot water on the plane to the U.S. Ripping the bag open to pour the tea-leaves into the cup, he was left with an undrinkable mess! Exceedingly puzzled by the West at first, nevertheless he began a worldwide mission to teach a spiritual path-of-the-heart for the Western world which grew to span seventy countries.

This spiritual path is significant for the West for many reasons: the importance placed on physical fitness to go hand in hand with the spirituality, a custom of his ashramite days, where he himself was decathlon champion in his youth. Secondly, the notion that this was not an era for removing to a cave to meditate alone, but to bring the fruits of meditationlife into the community. And thirdly, that each spiritual Master from Lord Krishna, down through the ages: Lord Buddha, Lord Christ, Sri Ramakrishna and so on; were players in a larger game, one he called the Divine Lila, or Cosmic Game - the goal of which was humanity's spiritual evolution into the Divine Consciousness. Although these ideas stem from Hinduism, they were not general knowledge in the West. The bringing together of the dynamism of the West and the spirituality of the East was a constant theme in Sri Chinmoy's work.

Sri Chinmoy attained the highest experience, God-realisation or Self-realisation (he did not distinguish between the two terms) at an early age; being the conscious awareness of unity with what he termed his Beloved Supreme.

I started praying and meditating - you can say unconsciously - at the age of four or five. But since the very beginning of my conscious spiritual journey, I have been praying to the Supreme not only for my own perfection in life but also for a oneness-world founded upon inner peace. At this point in my spiritual journey, all my prayers are for others, for the world, for peace. Then again, in the highest sense, there is no separation between myself and "others." After I attained my own conscious union with God, I came to realize that there is only one "person," and that is my universal oneness-lifef.

He uses the term Supreme often in place of God to denote an ever-transcending consciousness rather than the idea of God at a static level. Sri Chinmoy then undertook to manifest his own spiritual experience in many and varied fields of endeavour in order to inspire and awaken others. Often untrained, he dauntlessly entered fields of endeavour such as painting, drawing, tennis, ultra-running, weightlifting, writing and lecturing, poetry and music, travelling the world to give free concerts and play his own unique compositions on many different instruments.

When I became a student of Sri Chinmoy, in 1986, he had published around 750 books and pamphlets. The question was how to approach such a huge volume of work? On reading the poetry, certain themes kept recurring to me that suggested the tradition of The Quest: Separation, Trial and Return. The Quest of course is a universal theme in spiritual traditions. This I chose as my approach, to impose some order on the vast amount of work. At Sri Chinmoy's passing in 2007, there were well over 1500 books published. This paper is an overview of my updated thesis, The Ever-Transcending 
Quest in the Poetry of Sri Chinmoy, with the later writings of poetry and prose, (now published on the web) ${ }^{\mathrm{g}}$.

\section{Discussion}

From Sri Chinmoy's youth he wrote poetry, a little in French, but mainly in Bengali. Around age 22, one of the ashramites, Romen Palit, insisted that Chinmoy should write poems in English and taught him English metre one afternoon. He immediately wrote The Golden Flute, Revelation, and his classic poem, The Absolute. Since coming to the West in 1964 he wrote mainly in English. However Sri Chinmoy continued to write song-mantras in Bengali for the remainder of his life, some 17,000 which he put to music $^{\mathrm{h}}$. Sri Chinmoy's earlier work was more traditional and formal in style but in the U.S. his style progressed through the decades to become more aphoristic. This is clearly evident in the larger collections, Ten-thousand Flower-Flames, early 1980's, TwentySeven Thousand Aspiration-Plants, late '80s through '90s, and Seventy-Seven Thousand Service-Trees, begun late ' 90 s, of which 50,000 were completed.

\section{The separation}

The four steps of the Quest as I have envisaged it are further divided in smaller stages which cannot be covered at length here, however the major themes are demonstrated in this small sample. To explore the separation from divine consciousness, it is imperative to understand the theory of Oneness of all consciousness, and the involution of the soul from a higher realm into the dense physical world, which begins the individual game.

\section{UNRECOGNISED}

Humanity is divinity

Yet unrecognised.

Divinity is reality

Yet unrecognised.

Reality is totality

Yet unrecognised ${ }^{\mathrm{i}}$.

Sri Chinmoy's writings are replete with the knowledge of the ancient Indian scriptures.

Ekam sad viprā bahudhā vadanti

(Rgveda 1.164.46)

Truth-existence is one. Sages call it by various names'.

This 'truth-existence', Sri Chinmoy explains, is the basis of all the great religious traditions, represented in his own writings as the Supreme Consciousness which permeates the universe. We are taught that God is Omniscient, Omnipresent and so on, and Sri Chinmoy illustrates that it is through consciousness itself that we are linked with the highest, something that cannot be measured in a physical way.

Who is God? God is an infinite Consciousness. He is also the self-illumining Light.

There is no human being who does not own within himself this infinite Consciousness 
and this self-illumining Light... God is not something to be obtained from outside. God is that very thing which can be unfolded from within ${ }^{\mathrm{k}}$.

Sri Chinmoy often makes the assertion that the universe is consciously or unconsciously evolving into spiritual perfection ${ }^{1}$, and significantly that it is not only the physical world that evolves, but also the spiritual, the soul that is in evolution as a portion of the Supreme Being manifest on the physical plane of existence. He gives us the message of the Vedas in a distilled form, interpreting for a modern sensibility. For instance, where the Rig Veda speaks of Agni, the fire god, Sri Chinmoy speaks of aspiration "the fire of the inner awakening, the inner mounting flame"m, inherent in us, this an ever-climbing urge towards fulfillment for a human being is a central concept in his philosophy.

The following poems begin to illustrate the separation from Oneness with Godconsciousness with the descent into the physical world. Oneness before birth is forgotten, the Quest begins and so the 'Divine Lila' plays itself out over millennia. Although the lyrics seem simple, there is an underlying complexity and power that becomes more evident as the poet's world-view is understood ${ }^{\mathrm{n}}$. At once they evoke a higher level of conscious awareness and the wondrous cyclical game of life and evolution, as well as the pain of self-forgetfulness.

\section{CAME}

Into the world of beauty's-flame,

Into the world of offering's-game,

Into the world of lustre-flood,

I came, I came, my existence came ${ }^{\circ}$.

\section{HIDE AND SEEK}

It seems that I have lost something somewhere.

My eyes are pining for it,

My heart is pining for it,

But it is all hidden.

From time immemorial

You have been playing hide and seek with me.

This much I can recollect, that's all ${ }^{\mathrm{P}}$.

\section{ONLY THE OTHER DAY}

O Lord Supreme, only the other day

I saw You and played with You,

Before I came into the world of ignorance-night.

Yet I remember my golden past within and

without,

Alas, far, very far, now You are.

The bird of my heart is crying and trembling 
with darkest pangs ${ }^{\mathrm{q}}$.

'I Came' presents the idea of the soul consciously entering the Game, giving a startlingly different view of the world - a spiritual view. The world becomes a glorious place, perceived as a self-offering of the soul and the flood of light underlying reality. In 'Hide and Seek', helpless as a newborn, the seeker is not even sure for what he seeks; there is only awareness of the endless game of death and reincarnation and a lost goal. In 'Only the Other Day', Sri Chinmoy uses the trope the 'bird of my heart' to denote the soul, its fragility and suffering, caged in the physical world, as well as its potentiality for the freedom of flight, of liberation.

Sri Chinmoy has written and answered questions extensively on death and reincarnation, that after each lifetime we take a short rest in the soul's region and then come back into the world to resume our part in the Game. The following is an abridged extract:

In one lifetime on earth we cannot do everything. If we remain in the world of desire, we will never be able to fulfil ourselves. As a child we have millions of desires, and even when we reach the age of seventy we see that a particular desire has not been fulfilled and we feel miserable... Now our dearest is God. Do you think that God will allow us to remain unfulfilled? No! God's very purpose is to fulfil each individual and Himself through us. He will have us come back again and again to fulfil our desires... If we go through desire, we see that there is an endless procession of desires. But if we go through aspiration, we see the whole, we enter into the whole and eventually we become the whole. We know that if we can realise God, inside God we will find everything, for everything exists inside God. So eventually we leave the world of desire and enter into the world of aspiration.... It is through aspiration and evolution that the soul develops the full possibility of realising the Highest and fulfilling the Divine ${ }^{r}$.

There are many religions that acknowledge reincarnation. Despite translations through millennia, there are still traces of the teaching of the karmic laws of reincarnation in the Bible if we look carefully, for instance 'what you sow, you shall reap' and 'an eye for an eye', which have passed into the vernacular, refer to the universal laws of karma accumulated from one incarnation to the next.

Sri Chinmoy, as both Master and poet is constantly challenging and surprising us. There is often an irresistible logic in parallel statements. This is a literary device where statements are similar in their construction and persuasive due to repetition. They build upon each other, leading us to view things from the poet's point of view. We are led gently and surely to a conclusion that expands our perspective. In the next entitled 'Salvation' three seemingly disparate world-views of Christianity, Buddhism, and the path of Sri Chinmoy are compared, resulting in a compelling vantage point. We glimpse a further step in the evolutionary Game.

\section{SALVATION}

If you think of sin,

Then you need salvation.

If you think of ignorance,

Then you need liberation. 
If you think of oneness,

Then you need God-realisation, Self-realisation ${ }^{\mathrm{s}}$.

\section{TO SEE THE LIGHT}

To see the light

A tiny blade of grass

Remains wide awake all night.

To see the light

The buds offer their devoted eagerness.

Alas, neither a blade of grass nor the buds

Can awaken my aspiration-flame.

I sleep and sleep,

My ears tightly closed ${ }^{t}$.

Here a conceit is used to highlight the seeker's lack of inspiration to move towards the light. The lowly blade of grass and the buds are personified and endowed with a natural yearning, in contrast to the speaker's own predicament. Light, is operating on two levels, imbuing the grass and buds with patient humility or devotion, whereas the seeker is bereft of the aspiration for enlightenment, a reversal of the natural order. The compound noun 'aspiration-flame' challenges the notion of passive receptivity, illustrating it should be a conscious, dynamic experience. It recalls Walt Whitman, who uses this conceit, the innate humility of grass in his Leaves of Grass ${ }^{\mathrm{u}}$, and extends it into a symbol to explore both the multiplicity and the oneness or unity of the world around him.

\section{The trial}

In this sample of poetry categorised as the Trial, the seeker is tested and the intricacies of the profound inner relationship and interaction with the Supreme Consciousness is explored. The use of repetition and shifting in tone or point of view, illustrate the darker side of human nature. The dramatic inner battleground is drawn between the highest aspirations and the lowest moods, the loss of faith and despair.

In the following we are confronted with quite shocking ideas - that the mind is a liar, a beggar, set upon bringing about our demise. As we live in an age where the scientific mind is revered as the pinnacle of civilisation, we must rebel. We are drawn to read over again, suspend our disbelief, and eventually we are compelled to consider by the end of the piece that we can often be deluded by the mind - it does cause us to reason away, forget what we learned as children, that the Lord Christ said, 'the Kingdom of Heaven is within you'. An eternal truth is reasserted.

\section{NEVER BELIEVE WHAT YOUR MIND SAYS}

Never believe what your mind says.

Your mind is a liar.

Never believe what your mind says.

Your mind is a beggar.

Never believe what your mind says,

Your mind is secretly digging your grave. 
Never believe what your mind says.

Your mind tells you that God is somewhere else,

That God is someone else other than you ${ }^{v}$.

The finite, un-illumined, tricky human mind becomes a part of the trial itself. It is an illustration that Sri Chinmoy is drawing an inner canvas of trials, not the outer heroism of legend. To further explain that inner canvas, the following is one example; parallel statements show us the hierarchy, a more complicated nature of the inner self. Sri Chinmoy challenges us to examine again what it is we identify with deep within us - we can easily identify with the mind, body, heart, even soul, but we now are given an outline of another level - the vital, seat of emotion and desire.

\section{VISION-SKIES}

The body

Loves to be swayed by the wind of emotion.

The vital

Loves the prickings of desire.

The mind

Loves the confines of the finite.

The heart

Loves to be in the galaxy of saints.

The soul

Loves the life of unhorizoned vision-skies ${ }^{\mathrm{w}}$.

These levels of the inner being do have the ability unconsciously to sway us, and mask the voice of our own higher wisdom. Sri Chinmoy explains these inner planes of existence;

"Deep inside us there are seven lower worlds and seven higher worlds. We are trying to transform the lower worlds into luminous worlds, worlds of perfection, and, at the same time, we are trying to bring the higher worlds into outer manifestation. Some of the higher worlds we already see operating in our physical world, on earth. First comes the physical, then the vital, then the mind, then the plane of intuition or the intuitive mind, then the overmind and the supermind. After the supermind comes Existence-Consciousness-Bliss - Sat-Chit-Ananda. If you know how to observe them, you can see that some of these worlds are already functioning in you." ${ }^{\text {x }}$

The following lyric presents the spiritual seeker, unable to grasp the object of his search and heading towards despair with a series of rhetorical questions. Their imploring tone trails off wistfully at the close without resolution.

\section{BY WHOSE TOUCH}

By whose touch does the lily smile

And open its beauty-bud?

Whose moonlit beauty 
Do I see in the lily?

Who is the Eye of my eye;

Who is the Heart of my heart?

Alas, then why do I not see Him,

His Face of transcendental Beauty,

Even in my dreams? ${ }^{\mathrm{y}}$

The opening image characterises a poignant and ethereal relationship between the lily and the moon - the moon being an expression of the divine animating quality of light, and the lily responding by blossoming with a satisfying smile. This intimacy between a simple flower and the divine is then contrasted with the seeker's corresponding lack; a complicated fluctuating presence and absence in the human seeker where the surpassing beauty of the divine is withheld. It not only admits of the perception of the divine in the human, but also of the divine as the Perceptor; God and human as One, "Who is the Eye of my eye;/Who is the Heart of my heart?" The plaintive cry at the close places the lily back into unconscious nature by accentuating humanity's conscious aspiration and search for divinity. However, we are left with an impression of helplessness, being at the mercy of capricious dreams.

The ultimate expression of the fall into despair is attained in the following poem. Although it speaks indifferently of the loss of faith and direction, the point of view is undercut by the self-irony at the close.

\section{HAVE NOTHING}

I have nothing.

I have nothing to show or tell.

I have no spirituality, no worship,

No meditation, no adoration;

Nothing.

Around me are only inner pangs and

frustrations,

Dust, clay and ash.

I am satisfied with the world of

matter and desire.

I am compelled to be satisfied with little,

very little.

I have nothing ${ }^{2}$.

The enveloping structure and emotionless phrasing draws us into the undertone of stress to the point of paralysis. It contains both a dread and defiance in the face of the seeker's failure. And yet when the poet turns back to the secular world of matter and desire, it is found wanting against the wealth of the spiritual life. It is the secular life that is characterised as 'little, very little' at the close. The low pitch and cutting sense of rhythm express an overwhelming sense of loss, a cry from the abyss. The chanting tone gives inexorable emphasis to the oblivion, and the expression 'I am compelled ...' and illustrates a kind of stubbornness as well as the sense of being bitterly cornered. 


\section{BUTCHERED}

When I thought I was the doer

Of all my deeds,

I turned to mist,

I died.

I became the emperor of giant failures.

My soul came to the fore,

Consoled my visionless ignorance.

God made His Appearance supreme

"You fool, be not wedded to impossibility's

lifeless beauty.

I waste not a leaf.

I butchered your ignorance wild for you

To equal My Transcendental Throne"aa .

In the above, the impotence of the human and the power of the divine are juxtaposed existential man is refuted when divorced from his own inner divinity. Sri Chinmoy's consummate lyrical process of organising an experience from each different perspective into an experience of growth and illumination for the reader is demonstrated once again. God states it is absurd to think of the two as separate - man is simply a body of lifeless clay without the divine animating force. God states: "I waste not a leaf" and we recall the words of Kipling ${ }^{\text {ab }}$. There are often these oblique references to the laws of karma, reincarnation, and the Cosmic Game. The poem culminates in a reprimand by God and the reader participates in the ensuing transformation, becoming aware of a higher destiny and purpose.

\section{WAVES OF YOUR SMILE}

If and when I think that I shall not

invoke You any more,

I shall not even look at You,

But shall keep my eyes shut

And thus derive happiness,

I see You touching my eyes

With the waves of Your Smile.

I know not, Beloved, how and why

You are so close to me today.

Perhaps all this is just a mistake ${ }^{\mathrm{ac}}$.

Sri Chinmoy again expresses the lowest ebb of the seeker, with the petulance of the child, eyes tightly shut as if to obliterate. But the denial gives way to wonder under the confrontation with the image 'the waves of Your Smile', the divine Grace permeating all. The beauty of this intimate inner experience is captured in a few simple words, a palpable, rapturous encounter with God illustrating the omnipresence of the divine like radio-waves. The seeker responds with humility and bewilderment. The slow movement of syntax then mimics the re- 
awakening of spirit, and the resistance is transformed into endearment and mystery at the close.

\section{THE DARK NIGHT}

The dark night has at last ended.

I have now seen You

Inside the depth of my heart.

I do not know what magic abides inside me.

Around me is the desert,

Yet I am not parched with thirst ${ }^{\text {ad }}$.

Here the ancient motif that what man seeks is within is reaffirmed. There is a strength and a quiet certitude in the knowledge of the inner wealth waiting to be claimed. The intricate relationship between human aspiration and divine revelation begins to emerge. Once again we witness Sri Chinmoy's personal experience of this truth, the magic that can only be found within.

\section{The return}

A quiet power emerges in the next selection, in part due to the formal metre, but also due to the language portraying exalted states of fulfilment and blissful absorption into the Divine Consciousness. The first short piece, 'Beyond Speech and Mind', sees the poet step back allowing the reader to stand on the threshold of eternal revelation, aeons spread out like a feast before us. This poem also implies many of the previous steps the culmination of a long process of evolution, both personal and universal.

BEYOND SPEECH AND MIND

Beyond speech and mind, Into the river of ever-effulgent Light

My heart dives.

Today thousands of doors, Closed for millennia,

Are opened wide ${ }^{\mathrm{ae}}$.

THE MESSAGE OF SURRENDER

Today You have given me

The message of surrender.

I have offered to You

My very flower-heart.

In the dark night with tears,

In the unknown prison-cell of illusion,

In the house of the finite,

No longer shall I abide.

I know You are mine.

I have known this, Mother, 
O Queen of the Eternal ${ }^{\text {af }}$.

In 'The Message of Surrender', we see the Eastern invocation of God as the Mother with all its connotations of sweetness and intimacy. The 'Maya' or illusion, the deception of the physical world, and the frailty of the finite physical body, are broken. It is a paradoxical exchange, as it is She who bestows Her Grace upon the seeker allowing the miracle of surrender.

\section{SING BECAUSE YOU SING}

I sing because You sing.

I smile because You smile.

Because You play on the flute

I have become Your flute.

You play in the depths of my heart.

You are mine, I am Yours.

This is my sole identification.

In one Form You are my Mother

And Father eternal,

And Consciousness-moon, Consciousness-sun,

All pervading ${ }^{\text {ag }}$.

'I Sing Because You Sing' articulates the blossoming intimacy between the seeker and the Divine; a oneness so enveloping that the seeker is an extension, an instrument of the divine. It closes with a moving image of both the personal God and impersonal, the Infinite and Eternal, the ululating sounds echoing and expanding across the Universe. Here we witness the marrying of ideas of the Mother from the East, the Father from the West, the Lover and the Beloved as the flute of Krishna is recalled, the known and the unknown from the Upanishads, the Father-God and the Christ-Son as One. Sri Chinmoy seems to effortlessly bridge great philosophical divides, illumining universal spiritual truths.

In the following poems Sri Chinmoy explores the attainment of Self-realisation, or the God-realisation experience, the ultimate spiritual fulfilment. We find the heroic dimension of human experience drawn in the elevated language and the chanting pace of iamb, which lend a solidity of form and a majestic authority.

\section{REVELATION}

No more my heart shall sob or grieve.

My days and nights dissolve in God's own Light.

Above the toil of life my soul

Is a Bird of Fire winging the Infinite.

I have known the One and His secret Play,

And passed beyond the sea of Ignorance-Dream.

In tune with Him, I sport and sing;

I own the golden Eye of the Supreme.

Drunk deep of Immortality,

I am the root and boughs of a teeming vast. 
My Form I have known and realised.

The Supreme and I are one; all we outlast ${ }^{\text {ah }}$.

The slower four-foot line, and faster pace of the five-foot line create an elegant tension suggestive of stepping back and forth between the finite human and the infinite divine perspective. The image the 'Bird of Fire winging the Infinite' gives sudden unconstrained freedom, sweeping the reader upward along with the image. The 'secret Play,' 'Ignorance-Dream' are powerfully evocative of the Quest. The union with God is established as an experience of being absorbed into Light. The single 'Eye of the Supreme' infers that the third eye, the eye of knowledge is now open. It recalls the Biblical reference that "the Light of the body is the eye therefore if thine eye be single thy whole body shall be full of light" ${ }^{\text {"ai }}$. The fluctuating rhythm in the final line of each stanza arrests our attention so that we must pause to appreciate the enormity of the achievement being surveyed.

\section{THE ABSOLUTE}

No mind, no form, I only exist;

Now ceased all will and thought;

The final end of Nature's dance,

I am It whom I have sought.

A realm of Bliss bare, ultimate;

Beyond both knower and known;

A rest immense I enjoy at last;

I face the One alone.

I have crossed the secret ways of life,

I have become the Goal.

The Truth immutable is revealed;

I am the way, the God-Soul.

My spirit aware of all the heights,

I am mute in the core of the Sun.

I barter nothing with time and deeds;

My cosmic play is done ${ }^{\text {aj }}$.

Again, the more traditional form of this poem gives a sense of completion and integrity. There is a lack of personality allied with a sense of ubiquitous 'presence': read aloud the oratorical impact is majestic. Nevertheless, any sense of ego melts away into the ultimate image of fusion - 'mute in the core of the sun' as time and eternity, mortality and immortality, the fine and the Infinite have been integrated. The exultation and triumphant tones are held in balance by the simplicity of statements: 'I face the One alone/... I have become the Goal'. There is no further need for speech, nor bartering with karmic consequences, the cosmic game has been resolved. The profound assertion 'I am the way, the God-Soul' brings dramatically to mind the spiritual achievements of other Masters. It tantalises us with the revolutionary possibility that this state is indeed attainable. We witness the realisation through eyes of both awe and humility. 
Of course Sri Chinmoy did not write the poetry in the sequence that I have organised. 'The Absolute' was only the third poem he had written in English, and was published in Mother India at the Sri Aurobindo Ashram, October 1953. He was then age $23^{\text {ak }}$.

\section{The manifestation}

I am glad that I did not follow

The path of Nirvana.

Extinction is not my choice.

Action, action, divine action,

Forever and forever

Will be my only choice ${ }^{\text {al }}$.

Traditionally, the completion of the Quest sees the hero returning to society transformed, with some kind of benefit or prize, and it is fitting to equate this with what Sri Chinmoy terms 'manifestation', or the artistic and creative endeavours that his Beloved inspired him to embark upon. He always stated the activities he embarked upon were completely due to God's Command and His Grace for the sole purpose of serving humanity. Sri Chinmoy has indicated that reading his poetry, or indeed singing his song-mantras, can be utilised as a method of entering into this higher state of awareness for the seeker, singer or reader.

In Sri Chinmoy's commentary on the Vedas and Upanishads, he explores the idea of the universe as action, mired in the meshes of ignorance: "It is the knowledge of the supreme Self that can destroy the human ignorance of millennia and inundate the earth-consciousness with the Light and Delight of the ever-transcending and evermanifesting Beyond"am. It seems that Sri Chinmoy's writings go a long way to addressing some fundamental questions across many spiritual traditions. He uses plain language, yet it is an elevated message, illumining mystical truths about the purpose of life and the nature of man and God, worthy of interest and further comparative research.

Each human being

Has to do only one thing:

Unmask his divinity ${ }^{\text {an }}$.

Sri Chinmoy intimates that when we try to speak of God we are limited by the mind. Also our unconscious, bound human ego takes control. But when we have surrendered our ego, our will, to the highest in us, then the manifestation of the Supreme can be achieved. The result is that all action is imbued with divine purity, delight and power, something that Sri Chinmoy explained became a permanent reality in the physical world, both illumining the human being and fulfilling God. Sri Chinmoy explained that God's ancient dream was human aspiration, but his new dream was divine manifestation, as ever indicating the ever-transcending nature of God, his Beloved Supreme, who was progressing in and through the physical from lesser perfection, to a greater perfection.

In two words we can sum up the message of all the Upanishads: aspiration and manifestation. Aspiration is the way, and manifestation is the Goal. Aspiration is the 
song of the infinite, eternal Consciousness abiding within us. Manifestation is the dance of unity's multiplicity, within and without $\mathrm{us}^{\mathrm{ao}}$.

Sri Chinmoy spent over 40 years, based in New York City, sharing, teaching, manifesting his own highest spiritual realisation in order to inspire humanity, and make his manifestation of Light permanent in the physical world. All of his endeavours, the extensive recording of talks, of questions and answers, poetry, thousands of musical compositions, and thousands of painting-mandalas ${ }^{\text {ap }}$, are designed to awaken the inner spiritual aspiration. They arguably map almost every conceivable step of the human journey and illustrate the unseen higher and inner worlds of consciousness.

\section{SILENCE SPEAKS}

Silence is not silent.

Silence speaks.

It speaks most eloquently.

Silence is not still.

Silence leads

It leads most perfectly ${ }^{\text {aq }}$.

The above short piece we can see signified the basis of the entire path - that meditation is the perfect communion with God, and that God can and does speak to us, lead us, only when we are in that silent place. Indeed, when we enter the words, we begin not only to understand the message, but to feel the calming silence itself as we are drawn back to the beginning in contemplation.

In defiance of the brevity of his style, the universal is always present underlying the personal, the imagery distilled down to a specific concept or experience and then expanded beyond the physical world, reflecting Sri Chinmoy's wider vision. Below are two examples from many, of what I term the 'conversation poetry', the poet articulating/ manifesting inner conversations with his Beloved Supreme.

"My Lord, I am singing."

"Fine, that is what pleases Me."

"My Lord, I am dancing."

"Wonderful, that is what enchants Me."

"My Lord, I am suffering."

"No, My child, you are not suffering.

That is not true.

What is happening is that you

are having a series of experiences.

Furthermore, try to realise that it is I

who am having all the experiences

in and through you"ar.

"My Lord, is there anything sweeter than forgiveness?"

"Yes, My child, gratitude is by far sweeter than forgiveness."

"My Lord, is there anything more fulfilling than the feeling of oneness?" 
"Yes, My child, when you feel that you are the Eternal Lover and I am your Eternal Beloved, and when you feel that I am the Eternal Lover and you are My Eternal Beloved, the feeling of oneness is supremely transcended and immortally fulfilled"as ${ }^{\text {. }}$

It is astonishing to consider that this is not a simple literary contrivance, but an actual articulation, a record of an exchange. We are brought up short with the explication of a divine Will that, it is claimed, is unfathomable, unknowable, yet with some surprise we have to admit, it cannot be easily refuted. We are left in a higher contemplation on the nature of the divine.

Above all, Sri Chinmoy taught that the sacred can be more easily apprehended through the heart consciousness, as the psychic centre of being which is more spiritually evolved, being close to and receptive to the divine soul. For instance, our common experience of a 'flash of intuition', he explains as the message of the soul's Light. The difference between the mind consciousness and the heart consciousness is that the mind functions on an intellectual level after the age of twelve or thirteen, whereas the heart consciousness remains child-like, fresh, spontaneous and full of joy and able to identify with others. It is when we begin to meditate in the heart that we first feel the sincere inner cry, which is aspiration. Indeed, he wrote a significant amount contrasting and comparing the heartconsciousness and the mind-consciousness, and their respective roles in the spiritual evolution of humanity.

Sri Chinmoy has indicated over and again that the Supreme as the Inner Pilot resides in the heart of each one of us, and that this Inner Pilot can not be denied forever.

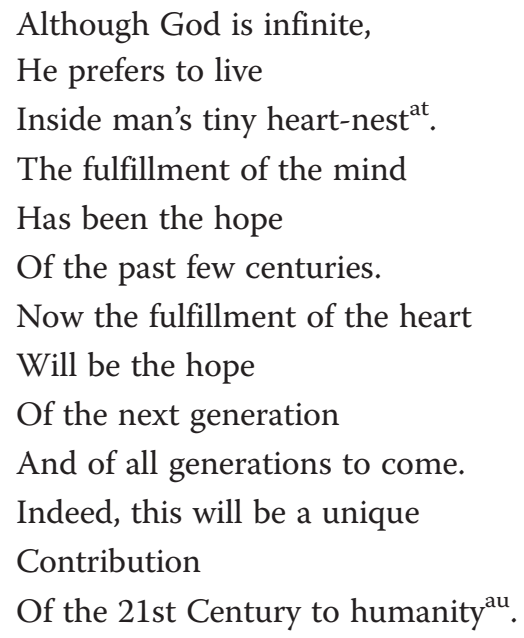

Sri Chinmoy teaches that the deepest inner self cannot be accessed by the mind because the mind is always busy, like a monkey, who cannot stay in one place. The mind is necessary for our functioning in the world, but it is often not a good leader. We can think and think, but we do not get illumination, or even satisfaction from the mind. One moment the mind extolls us to the skies, the next moment the mind tells us we are hopeless, helpless and stupid; one moment it is positive, optimistic, and the next moment it is negative. Therefore to meditate, the fastest way is to tap into the 
heart. He explains it is the heart where the soul resides, and it has the capacity to identify. The mind is limited, the heart is unlimited. The heart never complicates, it simply feels love, peace, abundance, oneness and joy. There are endless examples of this contrast throughout his writings.

Many people and of course the disciples who had the privilege of meditating with Sri Chinmoy perceived the aura emanating from him, of profound peace and love. When questioned about this, he stated:

As soon as I come in I bring down Light, Peace and Bliss from above. I bring down a sea of Peace, Light and Bliss, and this moves around like waves of the ocean ... I bring down the sea and represent the sea. In that wavy movement ... I am actually entering into each disciple. This white Light is the light of purity, inner purity and also it is the consciousness of God in the feminine form; that is to say, it is the Light of the Supreme ${ }^{\text {av }}$.

(Bennett 1991) has suggested that there cannot be a search for an ordered spiritual progression or diary of man's journey to God in the poetry of Sri Chinmoy. She explained that he never wrote in thematic sequence but like the flame of aspiration itself, flickered from one height to another, one theme to another ${ }^{\mathrm{aw}}$. Nevertheless, I have imposed my own order to try and gain some perspective on the work of over 100,000 poems. It is acknowledged the divisions are not always so distinct, there can be an overlap, or convergence across the steps of the Quest. Many of the poems I have used in the Return, were written early in the poet's life, however I have used the literary device of the Quest to illustrate how his work is imbued with these themes on both a personal level and a grander universal canvas. The Quest arose to me as a logical choice of theme to contain the study to a small, unified sample and illustrate dimensions of the transcendental vision of the poet.

No matter what the world thinks,

Our world,

Soon very soon,

Will be flooded with peace ${ }^{\text {ax }}$.

These words, one of a multitude of English song-mantras, illustrate Sri Chinmoy as the 'seer-poet' as he was sometimes proclaimed. He often states that humanity is on the brink of a new Golden Age where the ultimate goal is for each individual to manifest his or her own inner divine light in the world. Contrary to much of the darkness of popular opinion, his is an optimistic future for humanity. His work for both inner peace through meditation, and outer peace, supporting the United Nations, visiting international dignitaries, and multifarious other activities spanned four decades, yet he always claimed to be a student of peace. He maintained that each human being must be given complete freedom to find his or her own path to enlightenment, or realisation, as it is the Dream, the ever-transcending Will of the Supreme consciousness in his Own Cosmic Game.

Gazing into the future

I have come to learn 
That the world will one day

Succeed in bringing down

Infinity's Light from Above ${ }^{\text {ay }}$.

\section{Summary}

The writings of Sri Chinmoy can be personal and universal, the tone intimate as well as rhetorical, the style traditional, or modern, and aphoristic. However they often command the seeker to step directly into the viewpoint of the poet, a perception from God-heights which turns many of our older assumptions up-side-down. Sri Chinmoy explains many mysteries, that of the different levels of consciousness abiding in a human being, and their implications. Also, how a spiritual master must identify with suffering humanity, as well as show the way to the higher point of view. Many of his insights will have far-reaching ramifications for life, learning, art and spirituality into the future. This path of Sri Chinmoy stands like a lighthouse for humanity, blazing a way forward and encompassing all aspects of the physical world in order to transform it into the new golden age. It is, in fact, a significant new approach to spirituality, which can easily absorb the central truths of all religions while placing the responsibility clearly upon the individual. He illustrates time and again basic truths that the spiritual masters have expressed down through the ages - that the universe is permeated by a higher consciousness and that we are all manifestations of that force. It is the Dream, the ever-transcending Will of the Supreme consciousness in his Cosmic Game.

\section{Endnotes}

${ }^{a}$ Sri Chinmoy, Seventy Seven Thousand Service Trees, 1980-2009, No. 11,511; Although Sri Chinmoy passed in 2007, some of his work was still being transcribed, and published posthumously. Currently, over 1200 of his books are available online at http://www.srichinmoylibrary.com.

${ }^{\mathrm{b}}$ For example, there were financial constraints and strict rations in force at the Ashram in the early years, and it was not until well after the war that the problem of adequate nutrition for children was addressed; detailed in (Bennett 2012) Vidagdha, Under A Blue Pondicherry Sky, $25 \mathrm{ff}$.

'(Sri Chinmoy 1974c) Samadhi and Siddhi: The Summits of God-Life, 76ff

d(Bennett 2013) Vidagdha, Reverie, 123

${ }^{\mathrm{e} S}$ Sri Chinmoy, My Morning Soul-Body Prayers, Part 6, \#26 June

${ }^{\mathrm{f}}$ (Sri Chinmoy 1994) World-Destruction: Never, Impossible! Part 2, 19

${ }^{\mathrm{g}}$ This essay is adapted from an Honors Thesis for a Bachelor of Arts, Monash University, 1989. In my original thesis, Sri Chinmoy's poetry is discussed in relation to the American Transcendentalist Poets. Ref: http://www.srichinmoy-reflections. com/scholarly-studies

${ }^{\mathrm{h}}$ Mantra comes from the more mystical side of Eastern spiritual practice, being a sound or words uttered repeatedly to evoke that which they purport to represent, (the most well known being Aum, or Om, briefly the seed sound or vibration of the universe, used to evoke the Highest Consciousness).

iSri Chinmoy, Lord, Receive This Little Undying Cry, 44

'(Sri Chinmoy 1996) Commentaries on the Vedas, the Upanishads and the Bhagavad Gita, Three branches of India's Life-Tree, 30 
k(Sri Chinmoy 1970) Yoga and the Spiritual Life, 7

'(Sri Chinmoy 1996) Commentaries on the Vedas, the Upanishads and the Bhagavad Gita, Three branches of India's Life-Tree, 29

m(Sri Chinmoy 1996) Ibid, 69

${ }^{\mathrm{n}}$ Note: (Bennett 1991) Vidagdha writes extensively of the power in the simple lyrics in her book Simplicity and Power, The Poetry of Sri Chinmoy, 1971-1981

${ }^{\circ}$ Sri Chinmoy, My Flute, 36

${ }^{\mathrm{P}}$ J. M. \& H. Roberts, (Eds.) Selected Poetry of Sri Chinmoy, 36 (Translation from Bengali by poet)

${ }^{\mathrm{q}}$ Sri Chinmoy, My Flute, 59

${ }^{\mathrm{r}}$ (Sri Chinmoy 1974a) Death and Reincarnation, 91

${ }^{\mathrm{s}}$ Sri Chinmoy, Lord, Receive This Little Undying Cry, 103

${ }^{\mathrm{t}}$ Roberts, 25 (Translation from Bengali by poet)

u(Kaplan 1982) (Ed), Walt Whitman, Complete Poetry and Selected Prose, p.19

vSri Chinmoy, When God Love Descends, 28

${ }^{\mathrm{w}}$ Sri Chinmoy, The Dance of Life, Vol.1, 26

${ }^{x}$ (Sri Chinmoy 1974c) Samadhi \& Siddhi, 8

${ }^{\mathrm{y}}$ Roberts, 6 (Translation from Bengali by poet)

${ }^{\mathrm{z}}$ Sri Chinmoy, The Garden of Love-Light, Vol.1, 42

${ }^{\text {aa }}$ Sri Chinmoy, The Dance of Life, 35

${ }^{\mathrm{ab}}$ I quote (Sri Chinmoy 1974d) own reference in a public lecture 'Is Death the End', University of Kent, Canterbury on 11/11/1970, printed in The Inner Promise, 167: "Kipling's immortal utterance runs: They will come back, come back again, As long as the red Earth rolls. He never wasted a leaf or a tree Do you think he would squander souls? Each incarnation is leading us toward a higher life, a better life. We are in the process of evolution. Each incarnation is a rung in the ladder ... Man is progressing consciously and unconsciously ..."

${ }^{\text {ac }}$ Roberts, 27 (Translation from Bengali by poet)

${ }^{\text {ad }}$ Roberts, 26 (Translation from Bengali by poet)

${ }^{\text {ae }}$ Roberts, 21

${ }^{a f}$ Sri Chinmoy, My Flute, 60 (Translation from Bengali by poet)

${ }^{\mathrm{ag}}$ Roberts, 41. (Translation from Bengali by poet)

${ }^{\text {ah }}$ Sri Chinmoy, My Flute, 47

ai (Matthew 6.2)

${ }^{\text {aj }}$ Alan Spence, Ed. Between Nothingness and Eternity, Selected Poems of Sri Chinmoy, 62

${ }^{\mathrm{ak}}$ Note: These facts are now documented by Dr. Vidagdha (Bennett 2013) in her latest book, Reverie, Equilibrium Books, Aust. 2013, 37-49.

${ }^{a l}$ Sri Chinmoy, Seventy Seven Thousand Service Trees, No. 48,540

am (Sri Chinmoy 1996) Commentaries on the Vedas, the Upanishads and the Bhagavad Gita, Three branches of India's Life-Tree, 47

${ }^{a n}$ Sri Chinmoy, Seventy Seven Thousand Service Trees, No. 36,391

${ }^{\text {ao }}$ Sri Chinmoy, Commentaries on the Vedas, the Upanishads and the Bhagavad Gita, Three branches of India's Life-Tree, 93

${ }^{\mathrm{ap}}$ Many thousands of the songs of Sri Chinmoy are available at: http://www.srichinmoysongs.com

${ }^{\mathrm{aq}}$ Sri Chinmoy, Lord, Receive This Little Undying Cry, 123 
${ }^{\text {ar }}$ Sri Chinmoy, God's Secrets Revealed, 45

${ }^{\text {as }}$ Sri Chinmoy, God's Secrets Revealed, 84

${ }^{a t}$ Sri Chinmoy, Ten Thousand Flower-Flames, No. 7573.

${ }^{\mathrm{au}}$ Sri Chinmoy, The New Millennium, 50

av (Sri Chinmoy 1976) Perseverance and Aspiration, 62

${ }^{a w}$ Dr. V. (Bennett 1991) Simplicity and Power; The Poetry of Sri Chinmoy, 1971-1981, 1991, 229

${ }^{\mathrm{ax}}$ Sri Chinmoy, O My Heart's Silence-Shore Songbook, \#5

${ }^{\text {ay }}$ Sri Chinmoy, Seventy Seven Thousand Service Trees, No. 30,594

Competing interests

The author declares that she has no competing interests.

Received: 22 October 2013 Accepted: 21 April 2014

Published: 4 July 2014

\section{References}

Bennett, Vidagdha. 1991. Simplicity and Power; The Poetry of Sri Chinmoy, 1971-1981. New York: Agni Press.

Bennett, Vidagdha. 2012. Under A Blue Pondicherry Sky. Australia: Equilibrium Books.

Bennett, Vidagdha. 2013. Reverie. Australia: Equilibrium Books.

Kaplan, Justin (ed.). 1982. Walt Whitman, Complete Poetry and Selected Prose. New York: Viking.

Roberts, JM, and Roberts, H (eds.). 1980. Selected Poetry of Sri Chinmoy. New York: Agni Press.

Spense, Alan (ed.). 1982. Between Nothingness and Eternity, Selected Poems of Sri Chinmoy. London: Allestree Hill Books.

Sri Chinmoy. 1970. Yoga and the Spiritual Life. New York: Tower Publications.

Sri Chinmoy. 1971. God's Secrets Revealed. New York: Herder \& Herder.

Sri Chinmoy. 1972. My Flute. New York: Agni Press.

Sri Chinmoy. 1973. The Garden of Love-Light, vol. 1. Puerto Rico: AUM Press. 1973.

Sri Chinmoy. 1974a. Death and Reincarnation. New York: Agni Press.

Sri Chinmoy. 1974b. Mind-Confusion and Heart-Illumination. New York: Agni Press.

Sri Chinmoy. 1974c. Samadhi \& Siddhi. New York: Agni Press.

Sri Chinmoy. 1974d. The Inner Promise, Touchstone. New York: Simon and Schuster.

Sri Chinmoy. 1975a. Lord, Receive This Little Undying Cry. New York: Agni Press.

Sri Chinmoy. 1975b. The Dance of Life. New York: Agni Press. 1975.

Sri Chinmoy. 1975c. When God Love Descends. New York: Agni Press. 1975.

Sri Chinmoy. 1976. Perseverance and Aspiration. New York: Agni Press.

Sri Chinmoy. 1979. The Light of the Beyond. New York: Agni Press.

Sri Chinmoy. 1985. Ten Thousand Flower-Flames. New York: Agni Press.

Sri Chinmoy. 1992. O My Heart's Silence-Shore Songbook. Ho Chi Minh: City.

Sri Chinmoy. 1994. World-Destruction: Never, Impossible! Part 2. York: Agni Press New.

Sri Chinmoy. 1996. Commentaries on the Vedas, the Upanishads and the Bhagavad Gita. Three branches of India's

Life-Tree: Aum Publications, New York.

Sri Chinmoy. 1997a. God Is - Selected Writings. New York: Aum Publications.

Sri Chinmoy. 1997b. The Wings of Joy, Fireside. New York: Simon and Schuster.

Sri Chinmoy. 1998-2009. Seventy Seven Thousand Service Trees. New York: Agni Press.

Sri Chinmoy. 1999a. My Morning Soul-Body Prayers. NY: Agni Press. 1999.

Sri Chinmoy. 1999b. The New Millennium. New York: Agni Press.

Sri Chinmoy. 2002. The Divine Hero. London: Watkins Publishing.

Sri Chinmoy. 2010. The Jewels of Happiness. London: Watkins Publishing.

doi:10.1186/2196-8802-2-4

Cite this article as: Clarke: The ever-transcending quest in the poetry of Sri Chinmoy: the human quest for God-

Realisation; God's quest for manifestation. International Journal of Dharma Studies 2014 2:4. 